twardych faktów, potwierdzanych przez publikacje historyków i socjologów. Książka Sławomira Buryły przekonuje, że czas już pozbyć się etykietki skandalisty i pisarza kontrowersyjnego $\mathrm{w}$ odniesieniu do autora Uchodźców. Jednocześnie jest też mimowolnym dowodem na to, że to, co naprawdę wyjątkowe w pisarstwie twórcy tej klasy co Grynberg, kryje się w artystycznym przetwarzaniu faktów, idiomach i obrazach jego prozy i poezji. Największym osiągnięciem Grynberga są stworzone przez niego metafory i figury języka - a zatem wszystko to, co daje się ująć w kategoriach literackich, a umknąć musi kategoriom historycznym.

Olga Orzeł (Warszawa)

\title{
Twórcy polscy w RWE
}

Violetta Wejs-Milewska, Radio Wolna Europa na emigracyjnych szlakach pisarzy. Gustaw Herling-Grudziński, Tadeusz Nowakowski, Roman Palester, Czesław Straszewicz, Tymon Terlecki, Kraków: Wydawnictwo Arcana, 2007, 748 s.

Książkę Violetty Wejs-Milewskiej Radio Wolna Europa na emigracyjnych szlakach pisarzy. Gustaw Herling-Grudziński, Tadeusz Nowakowski, Roman Palester, Czesław Straszewicz, Tymon Terlecki uznać należy za pozycję wielce pożyteczną i interesująca. Autorka omawia radiowy ,epizod” w życiu każdego z przywołanych w tytule pisarzy, dbając o jak najpełniejsze odtworzenie jego związków z Radiem i to nie tylko tych formalnych, ale także personalnych (tu głównie relacji z Janem Nowakiem-Jeziorańskim). Przedstawia okoliczności, w jakich poszczególni twórcy trafili do Radia, formy współpracy, realizowane zadania, wreszcie warunki zakończenia pracy w RWE. Dodatkowo stara się w maksymalnie szerokim stopniu ukazać zakres poruszanych przez nich $\mathrm{w}$ audycjach radiowych tematów i w miarę możliwości wiernie odtworzyć ich poglądy (głównie polityczne i kulturalne).

Książka składa się z dwóch zasadniczych części — pierwszą stanowi pięć rozdziałów, w których przedstawieni zostali interesujący autorkę radiowcy, druga zaś (zatytułowana Komentarze - Recenzje - Felietony /Wybór/) jest obszernym, bo liczącym sobie 190 stron aneksem, na który złożyły się sumiennie przez Wejs-Milewską spisane teksty audycji przygotowanych przez jej bohaterów. Wartości tej drugiej części przecenić nie sposób - każde wydanie źródeł staje się cenną pomocą dla osób zainteresowanych twórczością i dokonaniami zarówno konkretnego autora, jak i — a taka sytuacja ma miejsce i w tym wypadku - pewnego środowiska, grupy osób połączonych wspólnymi dążeniami i celem.

W takim ogólnym przeglądzie pracy białostockiej badaczki zarzucić niczego nie można. Co więcej, należy uznać, że znad wyraz trudnego zadania, jakie przed sobą postawiła, wywiązała się dobrze. Jednak już w czasie lektury poszczególnych rozdziałów (szczególne wyraźnie rzuca się tu w oczy najobszerniejszy, a zarazem otwierający książkę, poświęcony Romanowi Palestrowi), nasuwa się szereg pytań i zastrzeżeń, którymi chciałbym się w tym miejscu podzielić.

Tym, co zwraca szczególną uwagę w omawianym tomie, są trzy kwestie, z którymi Wejs-Milewska musiała się zmierzyć podczas pisania swej rozprawy. Pierwszą jest dobór nazwisk twórców, których radiowe losy i sylwetki zostały nam bliżej przedstawione, 
drugą stanowi stopień szczegółowości opisu danej postaci i jej pracy w RWE, trzecią zaś, którą być może należałoby uznać za najważniejszą, sposób prezentacji radiowego dorobku piątki bohaterów tej dysertacji.

Warto zatem zapytać, jakie kryterium doboru zostało zastosowane w wypadku tej pracy, kryterium, które z całej galerii znakomitych postaci współpracujących z RWE pozwoliło wyłowić te pięć. We wstępie autorka pisze:

Na niniejszą książkę składa się pięć rozdziałów, każdy poświęcony konkretnej postaci, która dla polskiej kultury winna nie być obojętna. Dla każdego z autorów praca w RWE była ważnym etapem życia, w każdym jednak przypadku i w różnych okresach inaczej była przez nich samych oceniana. Niemniej mamy do czynienia ze spuścizną cenną, mającą zarówno charakter znakowy, jak i uniwersalny, bo można ją objąć w wielkim uproszczeniu słowem - felietonistyka (s. 19).

Przyznam, że nie do końca ów fragment rozumiem i to z kilku powodów. Po pierwsze powyższy opis nie mówi nic o specyfice wskazanych osób, a to z tego względu, iż można go odnieść nie tylko do nich, ale także do innych współpracowników monachijskiej radiostacji, wymienionych zresztą przez Milewską m.in. na stronie 18. Po drugie, pomijając już ów „charakter znakowy” (cóż to takiego? - czyżby chodziło o specyfikę, typowość owych zachowań przypisywanych środowisku RWE?), nie bardzo rozumiem, w jakim znaczeniu autorka używa tu słowa „uniwersalny”. Na ogół myśląc o uniwersalnym wymiarze działalności ludzkiej wskazuje się na jej jakość i zasięg oddziaływania - w terminie tym kryje się z jednej strony informacja o wymiarze ponadczasowym, jak i ponadterytorialnym (zreszta $w$ takim duchu zostało to słowo użyte przez autorkę po raz drugi na s. 23), a z drugiej o wysokim poziomie realizowanych działań. I o ile ostatnia ze wskazanych cech, o czym przekona się każdy, kto książkę Wejs-Milewskiej przeczyta, nie budzi większych zastrzeżeń, o tyle pierwsza nie powinna być chyba przyjmowana bez zarzutów. Radio Wolna Europa było i autorka $w$ swoich rozpoznaniach to potwierdza - medium nastawionym na bardzo konkretnego, krajowego odbiorcę, a co za tym idzie, operującym głównie językiem polskim. Już choćby te dwie przesłanki stawiają ową „uniwersalność” pod znakiem zapytania. A jeśli nawet zgodzić się na zawężenie tego terminu do wymiaru jedynie polskiego, to lektura spisywanych przez badaczkę audycji radiowych dowodzi, że dla współczesnego czytelnika nośnymi i wartościowymi wyda się zaledwie ich część. Wynika to zresztą z doraźnego charakteru felietonu jako takiego, a radiowego w szczególności, który dociera do odbiorcy (nawet zarchiwizowany) w ograniczonym zakresie, a będąc przy tym gatunkiem nastawionym na komentowanie aktualnych wydarzeń (po raz kolejny s. 23), z czasem traci na znaczeniu i wartości uniwersalnej właśnie, stając się jedynie świadectwem epoki.

Co interesujące, autorka jest świadoma, iż wskazane przez nią kryterium może być nieostre, stara się więc doprecyzować swoje stanowisko, kontynuując swój wywód następująco:

Uprawiali ją wszyscy moi bohaterowie: Roman Palester, Czesław Straszewicz, Herling-Grudziński, Tymon Terlecki i Tadeusz Nowakowski. Bardzo wiele ich łączy, sporo także dzieli, mają za sobą krótki[,] ale wspólny okres pracy w RWE, choć każdy rozpoczyna i kończy pracę $\mathrm{w}$ innym momencie, mają za sobą inne doświadczenia wojenne i powojenne, choć łączą ich międzypokoleniowe przeżycia powrześniowe, wszyscy realizują się równolegle, łącząc pracę dla radia z innymi żywiołami aktywności kulturalnej lub realizowali się wcześniej na innych polach. Dlatego są tak interesujący [...] (s. 19). 
I wszystko to prawda, tyle tylko, że także ta analiza dotyczy wielu spośród innych współpracowników RWE. Można wręcz powiedzieć, że znacznie trudniej byłoby wskazać osobę, która pracując w monachijskiej radiostacji wymienionych tu warunków nie spełniała.

Chciałbym być dobrze zrozumiany. Nie zarzucam autorce tego, że dokonała niewłaściwego wyboru opisywanych postaci — przeciwnie — uważam go za nad wyraz trafny (dlaczego, wyjaśnię za chwilę). Chodzi mi jedynie o metodologię, o usprawiedliwienie takiego postępowania badawczego, które zwerbalizowane w przytoczony sposób nie jest przekonujące i powoduje, że w trakcie lektury czytelnik cały czas stara się wskazywać na wyznaczniki, które mogłyby służyć usprawiedliwieniu takiego wyboru.

Równie frapujący, co zaznaczono powyżej, wydaje się problem szczegółowości opisu danej postaci i wiążąca się z tym sprawa prezentacji dorobku kolejnych bohaterów pracy. Należy tu wyraźnie zaznaczyć, że — i właśnie to odczytuję jako podstawowy wyznacznik arbitralności wyboru dokonanego przez Wejs-Milewską — badaczka przedmiotem swej refleksji uczyniła pióra znakomite, których wystąpienia radiowe charakteryzuje to, co w tym medium szczególnie cenne - wyrazistość, przejrzystość połączona $\mathrm{z}$ dużą umiejętnością egzemplifikacji i argumentowania, wysoka świadomość prawideł rządzących jednostronnym dyskursem medialnym, umiejętne i wyważone stosowanie chwytów retorycznych itp. A zatem kryterium doboru jest jakość i format przywoływanych bohaterów. W tym kontekście nie dziwi także, że i w tekście zasadniczym autorce nie udało się oprzeć pokusie obszernego cytowania poszczególnych wypowiedzi omawianych współpracowników RWE. Odbywa się to z pewnością z pożytkiem dla czytelnika, któremu wiele z tych tekstów jest prezentowanych po raz pierwszy, a podanie ich w formie pisanej stanowi dodatkową gwarancję możliwości ich wykorzystania w kolejnych opracowaniach, omówieniach czy choćby przypomnieniach. Równocześnie nie mogę się oprzeć wrażeniu, że tak obszerne cytaty, kuszące i smakowite w lekturze, jednocześnie rozsadzają od środka dyskurs badawczy — nie raz można spotkać całe strony, na których dwa obszerne passusy wybrane $\mathrm{z}$ audycji autorstwa np. Palestra czy Straszewicza powiązane są dwoma, trzema linijkami wypowiedzi badaczki, której nie udaje się w takiej sytuacji w pełni wykorzystać potencjału informacyjno-interpretacyjnego przywoływanych fragmentów, co odbywa się z widoczną szkodą dla jej własnego wywodu. Tak dzieje się, moim zdaniem, np. na s. 32, gdzie po obszernym cytacie, którego osią przewodnia jest, zdaniem piszącego te słowa, kategoria elementarnej uczciwości dążącego do ocalenia swej godności artysty, Wejs-Milewska chce w nim widzieć fragment odnoszący się do jego wolności (paradoksalnie kilka linijek niżej ponownie przywołuje słowa Palestra mówiącego o ,uczciwości artystycznej”). W podobnym duchu interpretuje badaczka wypowiedź przywołaną przez nią na s. 35 i po raz kolejny, moim zdaniem, nadmiernie eksponuje problem wolności zamiast — jak mi się wydaje — kluczowego nakazu zachowania godności i bycia uczciwym przede wszystkim wobec siebie samego. Naturalnie rozbieżności te są tu formułowane nie $w$ postaci zarzutu, lecz raczej pewnego postulatu badawczointerpretacyjnego, którego celem jest zwrócenie uwagi na możliwe odmienne odczytanie pewnych sformułowań czy sądów wychodzących z ust opisywanych przez Milewską radiowców. Dodać także należy, że tego typu rozbieżności w największym nasileniu narzucają się w najsłabszym, zdaniem piszącego te słowa, rozdziale pierwszym, który z powodu objętości (150 stron) i mnogości podejmowanych wątków tematycznych, jest najmniej zwartą i sprawiającą wrażenie niedopracowania częścią całej pracy. 
Pomijając te propozycje odmiennej interpretacji, chciałbym zwrócić uwagę na coś innego, coś, co wydaje mi się niepokojącą składową horyzontu badawczego autorki. Chodzi mianowicie o jej stosunek do poddawanych oglądowi „obiektów”. Celowo używam tu tego słowa, gdyż zakładam, że nie mogłoby się ono pojawić w ustach białostockiej badaczki. A nie mogłoby dlatego, iż — jak widać wyraźnie w całej książce - Wejs-Milewska zdradzając wyraźne zafascynowanie omawianymi radiowcami (dodajmy, że cechę tę uznać należy za niezwykle wartościową, gdyż ukazuje ona — jak wskazywała recenzentka wydawnicza książki — „głęboki humanizm” autorki), skraca (jak mi się wydaje nadmiernie) dystans do ich wypowiedzi i postaw. Naturalnie nikt nie neguje tego, iż wystąpienia Gustawa Herlinga-Grudzińskiego emanują emigracyjnym etosem i skupiają się na moralnym wymiarze egzystencji człowieka uwikłanego w problemy polityczne XX wieku, twórczość Romana Palestra zdradza nietuzinkową erudycję i nad wyraz rozległe horyzonty kulturalne, Czesław Straszewicz jako radiowiec realizował się przede wszystkim w tematyce politycznej traktując audycje w RWE jako składową pewnego większego dyskursu i nieustannie wykorzystywał ich polemiczny potencjał, Tymon Terlecki nawet przed mikrofonem pozostał przede wszystkim teatrologiem, zaś Tadeusz Nowakowski to celny ironista i stylista, a przy tym zaangażowany krytyk literacki. Paradoksalnie jednak eksponując te cechy, postrzegane w ogólnym oglądzie działalności radiowej przywołanych twórców, podczas ukazywania ich w kontekście konkretnych tekstów lub też w czasie poszukiwania argumentów za nimi przemawiających Wejs-Milewska nazbyt zbliża się do swoich bohaterów wierząc każdemu ich słowu i rozstrzygając wszelkie wątpliwości stwierdzeniami, które wydają się mi nieco... (proszę wybaczyć, ale nie znajduję innego słowa) naiwne. Aby nie pozostać gołosłownym, proponuję przyjrzenie się konkretnej realizacji tego procesu.

Wypowiadając się na temat przemian i zjawisk zachodzących w Polsce w latach 50. Roman Palester powtarza dwa - utrwalone w dużej części ówczesnej publicystyki emigracyjnej - przekonania. Jedno dotyczy powiązania ,totalistycznego mechanizmu doktryny" z konkretnymi osobami (ten pogląd Palestra referuje Milewska na s. 46), drugie zaś to założenie, że całość społeczeństwa polskiego jest ex definitione antykomunistyczna i w chwilach przełomowych jednogłośnie podejmuje ,walkę polityczną” z systemem (o tym traktuje cytat na s. 53). Naturalnie patrząc na to z dzisiejszej perspektywy, po analizach wielu historyków czy socjologów, dowiedzenie błędności tych tez nie stanowi problemu. Tego jednak Milewska nie czyni, lub inaczej — odnotowuje zaledwie drobną zmianę tonu wypowiedzi Palestra, jednak robi to dopiero w szkicu poświęconym... Starszewiczowi (s. 301). W bezpośrednim komentarzu do wystąpienia kompozytora nie dostrzega (lub — mówiąc ostrożniej — nie werbalizuje) tego, że tryb wypowiedzi skierowanej do odbiorcy krajowego zakłada pewien poziom retorycznej „nadwyżki”, patetycznej przesady, będącej swoistą odpowiedzią na krajową nowomowę. Stąd trudno oprzeć się wrażeniu, że słowa Palestra zwracającego się do rodaków w kraju:

Jeśli jednak my, którzy wprawdzie jesteśmy wolni ale tą wolnością, która zatruwa ciagłą i nieprzerwaną myśl o Waszej niewoli i Waszych cierpieniach, zdecydowaliśmy się mówić do Was o muzyce i sztuce, a zatem o rzeczach, które pozornie bardzo daleko są od tego co Was boli i co Wam najbardziej leży na sercu, to powodem tego jest oczywiście ta straszliwa zmora i ten ponury cień śmiertelnego komunistycznego niebezpieczeństwa, które przemożnym ciężarem kładzie się dziś nad ogromną częścią muzycznego świata (s. 38).

Wejs-Milewska czyta in extenso literalnie i dosłownie, nie dostrzegając ich romantycznej proweniencji, która w innym z cytowanych przez nią fragmentów ujawnia się jeszcze wyraźniej (,Jego [pisarza] miejsce jest razem z milionami ucieśnionych [!] 
i cierpiących — takie było zawsze zadanie i taki obowiązek wszelkiej literatury"; s. 46). W efekcie badaczka przyjmuje szereg diagnoz i analiz twórców emigracyjnych w trybie aksjomatu, uznając, że o ich prawdziwości świadczy samo (i to odbieram jako swoista, sygnalizowaną powyżej, naiwność) przebywanie na emigracji. W ten sposób rozumiem fragment, w którym pisze:

Jeśli Palester wydaje osąd skrajnie nieprzychylny dla postaw intelektualistów Zachodu i Wschodu — nie można go podejrzewać o nieznajomość rzeczy, o powierzchowność (tak dziś częstą i męcząca) czy o próbę zbudowania własnego autorytetu na umniejszaniu i deprecjonowaniu walorów innych twórców, szczególnie kiedy mówi o środowisku muzycznym i samej muzyce. Dlaczego jest więc tak wiarygodny? Wydaje się, że poza słowem jest coś jeszcze ważnego, dowód: jest czyn i dramatyczna próba, trudna decyzja o emigracji, rezygnacji z przywilejów[,] jakie dawał twórcy PRL-owski model kultury i jest też konsekwencja - niemal zupełna cisza panująca wokół kompozytora — jak sądzę — do dziś (s. 67-68).

W podobnym duchu pisze także o Straszewiczu (s. 295) i choć w obu wypadkach poszczególne tezy dotyczące obu felietonistów są z gruntu słuszne, to jednak sam wywód wydaje mi się wątpliwy. Przyłożenie bowiem tej miary, która została użyta w powyższym fragmencie, do członków zmagającej się z oficjalnymi władzami PRL opozycji, musiałoby skutkować odmówieniem im i ich dokonaniom jakiegokolwiek znaczenia, z czym zgodzić się nie sposób. Rzec by można, że Wejs-Milewska przyjmując sposób argumentacji emigrantów, w jakiś sposób jednocześnie go przejmuje, próbując z niego uczynić metodę opisu. Co więcej, nawet w chwili, gdy zdaje się dostrzegać „wysokie rejestry retoryki” pojawiające się w omawianej felietonistyce (s. 40), to swój brak wypowiedzi już niekoniecznie wartościującej, lecz jedynie sygnalizującej zdystansowanie się wobec takiego dyskursu tłumaczy tym, iż o ową cechę tekstów Palestra... nikt go nie zapytał (?!).

Oddając sprawiedliwość autorce, należy zaznaczyć, że na szczęście nie w całej książce ów dystans ulega tak gwałtownemu skróceniu - najgorzej wypada tu po raz kolejny rozdział poświęcony Palestrowi, choć i przy prezentacji innych opisywanych radiowców (Straszewicz, Nowakowski) zdarza się Wejs-Milewskiej podążać tym tropem.

Naturalnie obok takich, w książce natykamy się na analizy znacznie bardziej konstruktywne i rzeczowe:

[...] wydaje się, że jest jednym z pierwszych radiowców, którzy decydują się na swobodniejszy ton wypowiedzi, optuje bowiem Straszewicz za „mówieniem” do słuchacza, a nie „wygłaszaniem” doń mów, czym przełamuje koturnową konwencję, obowiązującą w pierwszych latach działalności radia. Dlatego o sprawach pierwszorzędnej wagi mówi w trybie dyskursu, nie unika przy tym ani kolokwializmów, ani często zabawnych neologizmów. [...] Wybór swobodnej rozmowy o polityce ma jeszcze jedno znaczenie: jest ważnym gestem dającym do zrozumienia, że polityka może być domeną zwykłego obywatela, „szarego człowieka”. Takie przeświadczenie stanowi przecież podstawę demokratycznego myślenia - o czym wielokrotnie w audycjach będzie Straszewicz przypominał (s. 301).

Widać wyraźnie, że Nowakowski jest szalenie wymagający i pełen powagi, gdy przychodzi mu oceniać literackie próby pisarzy krajowych zmagających się z problematyką traumy wojennej. Tam jednak, gdzie literackie obrazy przenoszą go jako czytelnika w przeszłość dawniejszą — z przełomu wieków, z dwudziestolecia, gdzie rekonstruują się zarówno znane, jaki i egzotyczne krajobrazy Polski, Nowakowski zdaje się być krytykiem łagodnym i melancholijnym. Nie znaczy to wcale, że w tych przypadkach rezygnuje z wymagań krytycznego warsztatu recenzenta (s. 520). 
Należy w tym miejscu autorce oddać, że widać w jej pracy wyraźne dążenie do zrealizowania celu, jaki został sformułowany we wstępie, gdzie pisząc bohaterach swojej dysertacji Wejs-Milewska zaznacza, że:

[...] ich pisarstwo radiowe winno być potraktowane jako dopełnienie biografii i oświetlenie jej emigracyjnego fenomenu w jego wymiarze maksymalistycznej aktywności, zrodzonej z przyjęcia na siebie obowiązku bycia wychodźcą politycznym (s. 19-20).

Potwierdza i doprecyzowuje ten cel na wstępie rozdziału poświęconego Gustawowi Herlingowi-Grudzińskiemu, gdzie zaznacza: „Bieżąca publicystyka radiowa, o której tu mowa, nie zmienia w zasadniczy sposób naszej wiedzy i nie wpływa na korektę oceny aktywności Herlinga-Grudzińskiego [...]”; po czym dodaje, iż „Na pewno jednak spuścizna radiowa Herlinga może tę wiedzę znakomicie dopełniać, ponadto raz jeszcze wprowadza nas w klimat czasu i klimat epoki [...]" (s. 188). Należy tu wyraźnie zaznaczyć, że — nawet przy zasygnalizowanych rozbieżnościach w jej wymowie czy nieco innych ocenach jej znaczenia - pogrupowana przez badaczkę tematycznie i poddana porządkowi chronologii przemian politycznych publicystyka radiowa omawianych pisarzy uzupełnia nasz stan wiedzy o elementy istotne i ważne.

Co więcej, pisząc swoją książkę Wejs-Milewska starała się unikać mówienia o rzeczach szeroko znanych (to niewątpliwa zaleta pracy). Naturalnie i one się pojawiają, co oczywiście zostało wymuszone przez opisywaną materię, jednak niejako w tle, odsunięte na plan dalszy wobec pierwszoplanowej „felietonistyki”. Wydaje się przy tym jednak (i to postrzegam już jako wadę), że tak poprowadzonym dyskursie badawczym autorka idzie zbyt daleko, odsuwając niekiedy badany tekst od jego macierzystego kontekstu na tyle, że ten drugi nie może już spełniać wobec tego pierwszego swej prymarnej roli — służyć weryfikacji wyrażanych sądów i ocen. Być może stąd rodzi się owo znamionujące szereg wypowiedzi badaczki zatracenie dystansu wobec obiektu badań. Wejs-Milewska - zapewne celowo, chcąc podkreślić walory literackie oraz zawartość ideową poszczególnych tekstów - nie konfrontuje ich z innymi wypowiedziami tego typu, z artykułami drukowanymi w prasie czy publikacjami książkowymi. W zamian (szacuję, że dotyczy to ok. $90 \%$ cytowanych tekstów) proponuje opis podobny do tego, jakim wprowadza do tekstu fragmenty felietonów Straszewicza, nie opatrując ich przy tym choćby najmniejszym przypisem (?!): „I krótkie dwie migawki z życia w kopalni złota i uranu, dziś dobrze nam znane dzięki dokumentacji, do powstania której m.in. swój ogromy wkład wniosło RWE” (s. 319).

W takich właśnie miejscach możemy rozpoznać Straszewicza-pisarza, zręcznego autora lapidariów, twórcę błyskotliwych i esencjonalnych dialogów, człowieka, który — jak mówił Tymon Terlecki — ,pisał z olbrzymimi oporami”, ale wszystko co napisał — podkreślał [??] jak Krok-Paszkowski — było świetne (s. 359).

Ten brak odniesień i dokumentowania przytaczanych czy formułowanych tez (choćby w pełni uzasadnionych) sprawia wrażenie irytującej maniery (por. m.in. s. 336, 495) dodatkowo wspomaganej przed drobne, publicystyczne wtraccenia wykraczające tematycznie poza zakres pracy, jak choćby zawarta w cytowanym fragmencie wstępu wycieczka pod adresem rzekomej współczesnej powierzchowności — jak rozumiem — prezenterów radiowych.

Nie mogę zresztą wykluczyć, iż wybór takiego dyskursu badawczego jest zabiegiem celowym, gdyż taki sposób prowadzenia opisu z jednej strony daje Wejs-Milewskiej możliwość zarysowania wyraźnych sylwetek swoich bohaterów, z drugiej zaś pozwala (na sygnalizowane już wcześniej), ,zwolnienie” się z obowiązku oceniania słuszności czy trafności ich analiz, co w wypadku twórczości publicystycznej o tematyce politycznej czy 
kulturalnej, mogłoby w znacznym stopniu wywód wzbogacić, choć jednocześnie zagmatwać. Zamiast tego otrzymujemy w książce ogólne, pozytywne oceny twórczości radiowej poszczególnych pisarzy, których pozostawienie w kontekstowej i badawczej izolacji ugruntowaniu tych opinii bynajmniej nie służy.

Można naturalnie przyjąć taki sposób pisania za dobrą monetę i uznać, że został on przez autorkę gruntownie przemyślany, a przeprowadzony bilans potencjalnych zysków i strat podpowiedział jej wybór takiej oto strategii badawczej, ale już za zupełnie niedopuszczalną uznać należy niedbałość dokumentacyjną, która zasygnalizowanej formie opisu towarzyszy i niestety zdarza się w książce dość często.

Nie dowiadujemy się np. jak liczna — choćby w dużym przybliżeniu — jest kolekcja pozostałych po Palestrze maszynopisów. Zamiast tego otrzymujemy informację głosząca, że „Iwią część archiwaliów stanowią maszynopisy do dziś właściwie nie znane" (s. 37). Podobnie nie rozumiem, dlaczego przypis pozwalający na lokalizację niezwykle istotnego, a przywołanego na s. 20 tekstu Romana Palestra Konflikt Marsja$s z a$, znalazł się na stronie... 32, zaś informacja o tym, gdzie znajduje się przywołana korespondencja Tadeusza Nowakowskiego i Juliusza Sakowskiego (s. 22) pojawia się dopiero na stronie 526! Analogicznie czytelnik, któremu nie wszystkie z przytoczonych faktów są znane, darmo szukałby w książce Milewskiej odsyłaczy do opracowań poświęconych przywoływanemu przez nią ,,wrocławskiemu Kongresowi Pokoju” z 1948 roku (s. 29), „łagowskiemu zjazdowi kompozytorów i muzyków (w 1949 roku)" (s. 29), czy informacji o tym, że Wiktor Trościanko (s. 18), postawiony przez autorkę w jednym szeregu z Kazimierzem Wierzyńskim, Józefem Wittlinem, Jerzym Stempowskim i innymi, nie był emigrantem nieprzejednanym w swej postawie wobec rządzonej przez komunistów Polski, lecz pełnił rolę kontaktu operacyjnego (KO) dla wywiadu PRL. Podobnie za nieeleganckie należy uznać to, że autorka przejmując pewne zwroty czy stwierdzenia swoich bohaterów, nie sygnalizuje tego stosownym przypisem. Mówi np. na s. 20 o skromności, jaką można dostrzec w przywołanym tekście Palestra Konflikt Marsjasza, nie dodając przy tym, że ową „skromność” jako pierwszy zauważył Herling-Grudziński, którego wypowiedź na ten temat badaczka cytuje na s. 33.

Pod tym względem książka pozostawia, niestety, sporo do życzenia. Ale jeśli dodatkowo spojrzeć na nią — a wobec skali zjawiska nie sposób o tym nie wspomnieć od strony edycji, to zakrawa ona na jakieś gigantyczne curiosum. Nie wiem, czy jego ostateczny kształt „zawdzięczamy” samej autorce (mam nadzieję, że nie!) czy też redaktorom i korektorom z Wydawnictwa Arcana, ale stwierdzić należy, że gdyby książce Milewskiej dane było być zgłoszoną do konkursu na najgorzej wydaną publikację roku, to śmiem przypuszczać, że zdeklasowałaby konkurencję bezapelacyjnie. Liczba błędów zawartych w tym opracowaniu poraża. Gdyby odczytać niektóre z nich dosłownie okazałoby się, że oto odkryto nowe dzieło Witkacego (Szewcy nota bene, s. 67), Roman Palester ,wszechstronny erudyta muzyczny” w swoich felietonach ,prezentował zarówno muzę (!) dawną, jak i XX-wieczną” (s. 37), zaś współpracownicy RWE nie cierpieli na kurcze łydek, gdyż radio stanowiło dla nich ,magnez [!] przyciągający niemal całą polską inteligencję pozostającą na Zachodzie” (s. 12).

Podobnie wiele do życzenia pozostawia interpunkcja - na s. 39 przed drugim, wyróżnionym z tekstu głównego cytatem znajduje się znak zamknięcia cudzysłowu, problem w tym, że nie wiemy, gdzie się ów cytat zaczyna, bo znaku otwarcia nie ma, na s. 18 brak dwóch przecinków, na s. 30 po skrócie tzw. brakuje kropki, na s. 32 w jednej z linijek tekstu znajdujemy zapis prawidłowy („Kultura” 1951, nr 7-8), aby zaledwie linijkę niżej otrzymać podobny, tyle że bez przecinka. Dodajmy, że przywołane — na wyrywki — przykłady, to zaledwie wierzchołek góry lodowej, a o edycji przypisów, 
cytatów, uzupełnień itp. lepiej w ogóle nie wspominać, chyba że na seminariach edytorsko-tekstologicznych lub naukach pomocniczych, gdzie praca Wejs-Milewskiej może być wyrazistym przykładem na to, jak książek wydawać nie należy.

Podsumowując, trzeba powtórzyć stwierdzenie początkowe, głoszące iż praca Radio Wolna Europa na emigracyjnych szlakach pisarzy jest pozycją interesującą i pożyteczną, a w warstwie przywoływania nieznanych szerzej źródeł zgoła nie do przecenienia. W sferze badawczej dysertacja z powodzeniem realizuje zasygnalizowany przez autorkę postulat poszerzania stanu istniejącej wiedzy przy jednoczesnym zachowaniu dotychczasowych ocen dorobku poszczególnych pisarzy. Co do samej metody formułowania, a następnie dowodzenia stawianych tez, to - w odczuciu piszącego te słowa - książka pozostawia szerokie pole do dyskusji, a niektóre uwagi czynione przez autorkę wydają się niesłuszne. Natomiast w zakresie dokumentowania faktów historycznych, literackich i radiowych praca w widoczny sposób niedomaga, zaś jej strona wydawniczo-redakcyjna jest absolutnie naganna.

Rafał Moczkodan (Toruń)

\section{Displaced Persons}

Christian und Marianne Pletzing (Hgg.), Displaced Persons. Flüchtlinge aus den baltischen Staaten in Deutschland. München: Martin Meidenbauer Verlagsbuchhandlung, 2007, 246 s., il.

Der Band 12 der Reihe Colloquia Baltica, den Marianne und Christian Pletzing herausgegeben haben, geht aus ein Seminar zurück, das die Academia Baltica in Lübeck mit der Gustav-Heinemann-Bildungsstätte in Malente unter dem Patronat des Honorarkonsulats der Republik Lettland in Schleswig-Holstein veranstaltet haben.

Vaira Vikse-Freiberga, bis Juli 2007 die Staatspräsidentin der Republik Lettland geleitet mit ihrem kurzen Text in die Thematik, in dem sie freilich die lettischen DPs herausstellt, gleichwohl beziehen sich ihre Behauptungen allgemein auf die Balten: „Im Exil ließen die Balten die Köpfe nicht hängen“, und in diesem Sinne erweitert die Verf. ihre Perspektive als sie zurecht feststellt:

Die baltischen Displaced Persons sind nicht nur ein Teil der lettischen, litauischen und estnischen Geschichte, sondern in gewisser Weise auch Bestandteil der deutschen Regionalgeschichte (S. 7-8).

Das Vorwort stammt von Feder Christian Pletzings, des Leiters der Academia Baltica in Lübeck. Er präsentiert die wenig bekannten Aspekte der Nachkriegszeit im historischen Bewusstsein von heute. Dabei stützt er sich auf die Pionierarbeit und auch das bisher einzige deutschsprachige Standardwerk zu den DPs im besetzten Deutschland von Jacobmeyer. Der Autor bemängelt richtig, dass vor allem die zahlreichen Erfahrungsberichte baltischer DPs aus den USA, Kanada und Australien in der Forschung kaum rezipiert worden seien. Folgerichtig verweist er mit Nachdruck auf die am Ende der Publikation abgedruckten Zeitzeugenberichte (S. 201-221). Den folgenden Beiträgen vorweg nimmt Pletzing summierend, dass es gerade der baltischen Gruppe der DPs eigen war, sich insbesondere aus Intellektuellen und Angehörigen des Bildungsbürgertums zusammenzusetzen. 